Marta Maksimczuk

Uniwersytet w Białymstoku e-mail:m.maksimczuk@uwb.edu.pl

ORCID: 0000-0001-7855-5469

DOI: 10.15290/mhi.2021.20.01.14

\title{
Rozwój teorii i praktyki stosowania fiskalizmu na świecie i w Polsce z odniesieniem do współczesnej sytuacji epidemii COVID-19
}

\begin{abstract}
ABSTRAKT
Kolejne kryzysy gospodarcze, (w tym kryzys spowodowany pandemią COVID-19), mają ze sobą wiele wspólnych cech odnoszących się do tej fazy cyklu koniunkturalnego. W każdym następnym pojawiają się też różnice - zwłaszcza jeśli chodzi o stosowane przez praktykę gospodarczą sposoby ich pokonywania wynikające $\mathrm{z}$ istniejących nowych realiów gospodarczych. W tym kontekście opracowanie podnosi problematykę ewolucji teorii i praktyki fiskalizmu na świecie i w Polsce - ważnego narzędzia ingerencji państwa w gospodarkę. Celem jest próba przedstawienia ewolucji poglądów z teorii i praktyki gospodarczej w kwestii podatków i fiskalizmu z możliwością pogłębiania rozważań nad takimi tego elementami, aspektami i kierunkami zmian, które odpowiednio zmodyfikowane do nowych warunków mogą być przydatne także współcześnie w poszukiwaniu dróg wychodzenia z kryzysów - w tym zwłaszcza z obecnego związanego z epidemią COVID-19. Postawiono hipotezę badawczą wskazującą na szczególne znaczenie fiskalizmu w warunkach załamań gospodarczych - w tym w obecnym kryzysie spowodowanym pandemią COVID-19, wskazując, że istnieją trudne do jednoznacznego sprecyzowania granice (górna i dolna) stosowania fiskalizmu. Zastosowano metodę opisową, wspartą elementami analitycznej, która posłużyła do przedstawienia ewolucji poglądów dotyczących podatków, fiskalizmu i długu publicznego oraz do zaprezentowania badań empirycznych w tym zakresie ze światowej literatury. Metodę opisową wsparto analizą przyczynowo-skutkową opisywanych zależności. Wyprowadzono uogólnienia i wnioski pozwalające pozytywnie zweryfikować stawianą hipotezę badawczą.
\end{abstract}




\section{ABStract \\ The Theory and Practice Development of Applying Fiscalism in the World and Poland Regarding the COVID-19 Modern Epidemic Situation}

Subsequent economic crises (including the COVID-19 crisis) have shared many common characteristics relating to this phase of the business cycle. In each subsequent, their differences also appear-especially in terms of the methods used by economic practice to overcome them, resulting from existing new economic realities. The main topic addressed by this paper is the evolution of theory and practice of fiscalism both in Poland and the world. The subject has aimed at presenting a study providing an overview including taxation and fiscalism with the potential for further consideration of aspects and directions of change which, suitably modified for the new conditions, may also be helpful nowadays in seeking ways out of economic crises, especially the most recent one related to the COVID-19 pandemic. A research hypothesis pointing to the special importance of fiscalism in the conditions of economic breakdowns including the current crisis caused by the COVID-19 pandemic, indicates that it is difficult to unequivocally clarify the boundaries (upper and lower) of the application of fiscalism. The descriptive method, supported by analytical elements, illustrates the evolution of views on taxes, fiscalism, and public debt and present empirical studies in this field from the global literature. Furthermore, the method was supported by a cause-effect analysis of the described relations. Finally, generalizations and conclusions allowing to verify the previously stated research hypothesis were derived.

Słowa kluczowe: podatki, fiskalizm, kryzys, redystrybucja, dług publiczny, finanse publiczne

Key words: taxes, fiscalism, crisis, redistribution, public debt, public finances

\section{Wprowadzenie}

Omawiane zagadnienia odnoszące się do ewolucji teorii i praktyki stosowania fiskalizmu na świecie i w Polsce. Nie należą one do relatywnie najnowszych, pozostają jednak wciąż ważnymi i aktualnymi we współczesnej gospodarce, szczególnie w obecnych warunkach nasilania się zjawisk kryzysowych - w tym ostatnich, spowodowanych epidemią COVID-19. Zakres fiskalizmu we współczesnej gospodarce zmienia się z wyraźnie dostrzeganą tendencją wzrostową. Prowadzi to także do zmian poziomu innych makroekonomicznych wielkości (m.in. długu publicznego) i relacji (m.in. stopa wzrostu, PKB per capita i wielu innych). Dodatkowo należy zwrócić uwagę na określone bieżące i 
przyszłe (średnio- i długookresowe) skutki społeczno-gospodarcze wywierane przez fiskalizm wszystkim podmiotom gospodarującym.

Celem niniejszego opracowania jest próba przedstawienia ewolucji poglądów z teorii i praktyki gospodarczej w kwestii podatków i fiskalizmu z możliwością pogłębiania rozważań nad takimi elementami, aspektami i kierunkami zmian, które odpowiednio zmodyfikowane do nowych warunków mogą być przydatne także współcześnie $\mathrm{w}$ poszukiwaniu dróg wychodzenia $\mathrm{z}$ kryzysów - w tym zwłaszcza z obecnego związanego z epidemią COVID-19. Postawiono hipotezę badawczą, że: problematyka fiskalizmu i długu publicznego jest wciąż ważna i we współczesnej gospodarce nabiera szczególnego znaczenia - zwłaszcza w warunkach poszukiwania dróg wychodzenia z kryzysów.

Treść zasadnicza opracowania została podporządkowana realizacji przyjętych założeń wynikających z obranego celu i weryfikacji postawionej hipotezy badawczej. Składa się ona z trzech części. W pierwszej zaprezentowano zarys rozwoju podejścia do podatków i fiskalizmu w myśli prawno-ekonomicznej od starożytności po współczesność. Druga część opracowania podnosi kwestie odnoszące się do zakresu (granic) stosowania podatków i fiskalizmu. Rozważania teoretyczne wsparto odtwórczo wybranymi ze światowej literatury wynikami badań empirycznych dotyczących zależności między stosowanym zakresem fiskalizmu a osiąganymi wskaźnikami wzrostu i rozwoju. Trzecia, najbardziej nawiązująca do współczesności, odnosi się do szczególnego znaczenia fiskalizmu w sytuacjach kryzysu. Konkluzje i wnioski z zaprezentowanych w poprzedniej części badań empirycznych dotyczących zwłaszcza kryzysu z 2008 r., na tle wyników badań przebiegu i współczesnej modyfikacji długich cykli koniunkturalnych, odniesiono do obecnego kryzysu wywołanego epidemią COVID-19.

Zastosowanie miały dwie metody badawcze - głównie opisowa, wsparta także elementami analitycznej. Metoda opisowa posłużyła do prezentacji ewolucji poglądów odnoszących się do podatków, fiskalizmu i długu publicznego oraz do odtwórczej prezentacji badań empirycznych dostępnych w światowej literaturze. Metodę opisową wsparto analizą przyczynowo-skutkową opisywanych zależności. Z czynionych rozważań wyprowadzone zostały uogólnienia i wnioski pozwalające zweryfikować wcześniej postawioną hipotezę badawczą.

\section{Zarys rozwoju podejścia do podatków i fiskalizmu w myśli prawno-ekonomicznej od starożytności po współczesność}

Podatki i z nich wynikający fiskalizm towarzyszą człowiekowi od początku jego istnienia ${ }^{1}$. Prezentację, nawet najbardziej ogólnego zarysu ich ewolucji, zacząć należy od analizy tzw. fiskalizmu rzymskiego. Obowiązek ponoszenia

1 A. Gomułowicz, D. Mączyński, Podatki i prawo podatkowe, wyd. 8, Warszawa 2016, s. 31; N. Gajl, Teorie podatkowe w świecie, Warszawa 1992, s. 22-30. 
ciężarów związanych ze sprawami wspólnymi był tam rozłożony między obywateli. W czasach cesarstwa, w związku z prowadzeniem wojen zewnętrznych, zaczęto stosować obciążenie zwane „tributum”, potraktowane jako: „swoista inwestycja $\mathrm{w}$ wojnę poczyniona $\mathrm{z}$ myślą o zyskach (...) a państwo życzyło sobie, aby było postrzegane jako nieuciążliwe, składane dobrowolnie, a nie egzekwowane pod przymusem"3. Stopniowo wprowadzano wiele innych (vectigalia) świadczeń. Rzymski fiskalizm stawał się zjawiskiem coraz bardziej złożo$n^{n}{ }^{4}$. Państwo rzymskie okresu cesarstwa nie miało jednak wypracowanego i w praktyce sprawnie funkcjonującego systemu podatkowego zintegrowanego z gospodarką. W ogólnej ocenie wielu badaczy „był to raczej bezładny gąszcz szczególnych, często regionalnych, podatków, które nie pełniły roli instrumentów kontroli procesów gospodarczych, jak jest dziś”s.

W średniowieczu i w późniejszym okresie znaczący wkład do rozwoju teorii podatkowych wnieśli głównie kameraliści (J.H.G von Justi). Ich myśl przez ponad 200 lat wpływała na rozwój poglądów dotyczących podatków zwłaszcza w odniesieniu do ich miejsca w życiu społeczno-gospodarczym i znaczenia fiskalnej funkcji podatków i państwa ${ }^{6}$. Można tu znaleźć nawiązanie do nurtu chrześcijańskiej filozofii moralnej św. Tomasza z Akwinu i jego tezy, że „jeżeli panujący wymuszają przy użyciu przemocy coś w sposób niewłaściwy, to jest to rabunek, taki sam jak rozbój na drodze"7. Znajdowała ona także wyraz w poglądach odnoszących się do polityki fiskalnej, w której funkcja dochodowa podatków miała odgrywać szczególną rolę. Z kolei fizjokraci tezę kameralistów o potrzebie rozwoju produkcji przemysłowej i handlu zastąpili koniecznością rozwoju rolnictwa. Tym samym ulokowali tam również główne źródło dochodów państwa w postaci tzw. podatku jedynego. Jednakże (pomimo ważnych treści poznawczych tzw. tablicy ekonomicznej F. Quesnaya) ich koncepcja, nie znajdując zastosowania $\mathrm{w}$ gospodarce (negatywnie zweryfikowana przez K. Fridrich von Baden, próbującego wprowadzić ją w swoim księstwie), nie wyszła poza jej aspekt historyczny ${ }^{8}$.

Nie ulega wątpliwości, że wraz z rozwojem gospodarki rynkowej (kapitalizmu) rosło zainteresowanie podatkami i polityką fiskalną państwa. Należy więc przedstawić definicję podatku stosowaną przez Jeana B. Say’a. Twierdził on, że „podatek stanowi tę część produktu narodowego, która z rąk obywateli

2 P. Krajewski, Finanse publiczne, [w:] Rzymskie prawo publiczne, red. B. Sitek, P. Krajewski, Olsztyn 2004, s. 109.

3 A. Pikulska-Radomska, Uwagi o rzymskim fiskalizmie epoki wczesnego cesarstwa, „Studia Iuridica Toruniensia" 2012, t. 10, s. 38 .

4 Ibidem, s. 48.

5 P. Krajewski, op. cit., s 109

6 N. Gajl, op. cit., s. 37-40.

7 A. Gomułowicz, D. Mączyński op. cit., s. 39.

8 Ibidem, s. 42. 
przechodzi do rąk rządu dla zaspokojenia konsumpcji publicznych, (...) jest to zawsze ciężar nałożony na osoby prywatne lub ich zrzeszenia przez władzę zwierzchnią: naród albo monarchę, aby ich kosztem dostarczyć środków na cele konsumpcyjne, jakie ta władza uzna za właściwe”, „podatek jest to wartość uiszczona rządowi przez obywateli na pokrycie wydatków publicznych" ". Nawiązywały do niej inne późniejsze koncepcje. Była ona też punktem odniesienia wielu dalszych rozważań nad zakresem i granicami (z punktu widzenia zarówno podatnika, jak i państwa) stosowania fiskalizmu i analizy jego skutków społecznogospodarczych.

Zasady sformułowane przez Adama Smitha ${ }^{10}$ w znacznej części wciąż aktualne, wymieniane obecnie w sformułowaniu: równość, pewność, dogodność, taniość uzyskały charakter klasycznych zasad podatkowych. Równość można osiągnąć, zdaniem A. Smitha, drogą powszechnego i proporcjonalnego opodatkowania dochodów uzyskiwanych przez obywateli pod opieką państwa. Smith twierdzi, że „poddani każdego państwa powinni przyczyniać się do utrzymania rządu w jak najściślejszym stosunku do ich możliwości"11. Pewność oznacza, że „podatek, jaki każda jednostka obowiązana jest płacić, powinien być określony, a nie dowolny"12. Podatnik powinien tym samym z góry wiedzieć, jakie podatki, w jakiej wysokości i w jakich terminach zobowiązany jest zapłacić. Tak pojmowaną pewność zagwarantować musi państwo. Dogodność opodatkowania pojmuje się następująco: „każdy podatek winno się ściągać w takim czasie i w taki sposób, by podatnikowi było jak najdogodniej go zapłacić"13. Ma to na celu zminimalizowanie możliwości wystąpienia sytuacji, w której podatnicy nie będą dysponowali środkami potrzebnymi do uiszczenia należności. Autor zauważył, że: „ponieważ może on [tj. konsument] również według własnego uznania albo kupować, albo nie kupować, przeto jeżeli tego rodzaju podatek staje się dla niego kiedykolwiek uciążliwy, trzeba uznać, iż dzieje się tak z winy podatnika"14. Należy jednak wskazać, że A. Smith mówiąc o podatkach pośrednich, miał na myśli jedynie akcyzę od towarów uznanych za luksusowe. Z kolei podatki od artykułów zwykłych uważał za szkodliwe ${ }^{15}$. Taniość opodatkowania to postulat niskich kosztów poboru podatku. Badacz bierze pod uwagę zarówno „sumę, jaką podatek zabiera z kieszeni ludności”, jak i „sumę, której do kieszeni ludności nie dopuszcza” ${ }^{16}$. W obu przypadkach chodzi o utrzymanie kosztów poboru podatków na jak najniższym poziomie.

9 J.B. Say, Traktat o ekonomii politycznej, czyli prosty wykład sposobu, w jaki się tworza, rozdzielaja i spożywaja bogactwa, Warszawa 1960, s. 760.

10 A. Smith, Badania nad natura i przyczynami bogactwa narodów, Warszawa 2003, s. 585 i n.

11 Ibidem, s. 500.

12 Ibidem, s. 501.

13 Ibidem.

14 Ibidem, s. 502.

15 G. Szczodrowski, Polski system podatkowy. Strategia transformacji, Gdańsk 2002, s. 33.

16 A. Smith, op. cit., s. 502 i n. 
David Ricardo w swojej teorii ekonomicznej analizował także niektóre kwestie dotyczące fiskalizmu. Punktem wyjścia jego prawno-ekonomicznych rozważań nad opodatkowaniem była definicja: „Podatki są częścią produktu ziemi i pracy całego kraju, oddawaną do dyspozycji rządu. Płaci się je zawsze w końcu z kapitału lub z dochodu kraju"17. Nie ulega wątpliwości, że wkład D. Ricardo w rozwój teorii i praktyki stosowania fiskalizmu jest ogromny. Rozwinął koncepcje przerzucania (dystrybucji) ciężarów opodatkowania na różne klasy społeczne. Zaprezentował logiczne wywody prowadzące do stworzenia spójnego zestawu kanonów polityki fiskalnej ${ }^{18}$. Niewątpliwie warto przedstawić także poglądy innych przedstawicieli np. S. Sismondiego, nie tylko z powodu uznawania podatków za lepszą formę finansowania wydatków rządowych niż pożyczki, ale zwłaszcza z tytułu jego twierdzenia, że: „żaden pomysł zapewne nie był zgubniejszy dla ludzkości od pożyczek publicznych, żaden też nie wywołuje większych złudzeń"19.

Na gruncie liberalnej myśli ekonomicznej (A. Smith, D. Ricardo) powstały późniejsze, znaczące koncepcje podatkowe. Nakazywały one w szczególny sposób chronić dobro prywatne (podatnika) w kolizji z publicznym (państwo). Zostały tam również zarysowane reguły przerzucalności podatku. Kierunek myślenia (L. von Stein, A. Wagner) szkoły niemieckiej o podatkach odmiennie od idei liberalizmu ekonomicznego sformułował założenia swojej koncepcji. Zagadnienia opodatkowania rozpatrywał w kontekście ogólnej koncepcji państwa i odnosił je głównie do zadań, które ma ono spełniać. Zobowiązywał państwo do słusznej i sprawiedliwej korekty dochodu narodowego z wykorzystaniem socjalnej funkcji opodatkowania. Z kolei J.M. Keynes wskazywał szczególne znaczenie roli podatków $\mathrm{w}$ polityce interwencyjnej państwa w każdej fazie cyklu koniunkturalnego ${ }^{20}$. Nie można pominąć również myśli podatkowych XX w., zawartych w tzw. nowej szkole niemieckiej (F.K. Mann, W. Gerloff, F. Neumark) podkreślających potrzebę zachowania ciągłości w nauce o podatkach.

Reasumując rozważania o ewolucji wybranych i charakteryzowanych koncepcji podatkowych można wskazać, że do najważniejszych ich cech wspólnych można zaliczyć:

a) Podatki i z nich wynikający fiskalizm zawsze budziły w różnej skali nasilające się emocje, spory i kontrowersje.

b) Człowiek zgodnie ze swoją naturą pożąda pieniędzy, a państwo pożąda podatków z natury swojej organizacji i przesłanek funkcjonowania,

17 D. Ricardo, Zasady ekonomii politycznej i opodatkowania, Warszawa 1957, s. 168.

18 Ibidem, s. 168 i n.

19 J.C.I. Sismonde de Sismondi, Nowe zasady ekonomii politycznej, czyli o bogactwie i jego stosunku do ludności, t. 2, Warszawa 1955, s. 181.

20 A. Gomułowicz, D. Mączyński, op. cit. s. 68-83. 
poszukiwano sposobów rozwiązania konfliktu między interesami prywatnymi a publicznymi.

c) W teorii i praktyce funkcjonowania podatku nie udało się $\mathrm{w}$ pełni rozwiązać problemu sprawiedliwego podziału dochodów między jednostką a państwem.

d) Zagadnienia podatkowe rozpatrywano w kontekście istniejących uwarunkowań funkcjonowania społeczeństwa i gospodarki.

e) Opowiadano się za potrzebą tworzenia racjonalnych systemów podatkowych, jednak istotę racjonalności pojmowano różnorodnie.

Poglądy reprezentantów tzw. nowej szkoły niemieckiej, wskazywały na potrzebę zachowania ciągłości w nauce o podatkach. Uważali oni, że: „Bez zrozumienia instytucji podatkowych i towarzyszących im uwarunkowań ujętych $\mathrm{w}$ dawnej myśli podatkowej nie jest możliwe budowanie od podstaw nowego porządku podatkowego. Ewolucja myśli podatkowej umożliwia nie tylko wartościowanie, lecz także dokonanie weryfikacji oraz oceny znaczenia i osiągnięć dawnych koncepcji podatkowych"21.

Oczywiste jest, że koncepcje podatkowe nie mogą być niezmienne w czasie. System podatkowy, jego strukturę, rodzaje i treść tam znajdujących się podatków i w praktyce stosowane formy opodatkowania należy pojmować jako wyraz dokonujących się przemian w życiu społeczno-gospodarczym i politycznym.

\section{Próby regulowania zakresu podatków i fiskalizmu. Wybrane przykłady rozważań teoretycznych wsparte wynikami badań empirycznych}

Wraz z podatkami i fiskalizmem pojawiały się także, stopniowo coraz wyraźniej zarysowywane, kwestie dotyczące zakresu ich stosowania. Znajdujemy je już nawet w najstarszych zapisach - m.in. w dotyczących samoopodatkowania i podatku pogłównego w związku z budową arki Noego. Analizując ewolucję „tributum” i historię rzymskiego fiskalizmu epoki cesarstwa dostrzegamy też wzmianki o ich zakresie i granicach stosowania. Podkreślenia wymaga fakt, że już ówczesne proste ich reguły, odnoszące się do idei powszechności i sprawiedliwości, zarysowywały znamiona tych dwóch filarów, na których w przyszłości opierać się będzie opodatkowanie - w tym także współczesne ${ }^{22}$.

O granicach (zakresie) opodatkowania i fiskalizmu świadczą w szczególności: wysokość i sposób (reguła) naliczania, częstotliwość i forma pobierania oraz kto jest płatnikiem. Powoływany wyżej podatek pogłówny, w wysokości pół szekla rocznie, obciążał wszystkich mężczyzn powyżej 20 roku życia 
zgodnie z regułą „bogaty powinien dać nie mniej, biedny nie więcej niż pół szekla"23. Przyjęte tam rozwiązania sięgały do idei „biblijnego podatku świątynnego" jako „ofiary zarządzonej jeszcze przez Mojżesza w takiej wysokości jako okupu za życie, aby w ten sposób powstrzymać gniew Boga"24. Obowiązywał on wszystkich dorosłych Żydów bez żadnych odstępstw w tej samej wysokości do czasu zburzenie świątyni jerozolimskiej w 80 r. po Chrystusie. Z kolei w Rzymie cesarski podatek pogłówny (tzw. tributum capitis) był corocznie nakładany na każdego obywatela od 12 (wolni mężczyźni od 14) aż do 65 roku życia w zależności od wielkości posiadanego majątku i jego dochodu ${ }^{25}$. Tributum ${ }^{26} \mathrm{w}$ czasach Cesarstwa Rzymskiego przechodził swoją ewolucję. Może być także doskonałym odzwierciedleniem specyficznej ewolucji zakresu rzymskiego fiskalizmu epoki cesarstwa i podejmowania prób wyznaczania skrajnych jego granic ${ }^{27}$ :

1. Unikanie pobierania (według Cycerona dostrzegającego w tych obciążeniach zamach na obywatelską pozycję);

2. Czasowe pobieranie w związku z prowadzonymi wojnami zewnętrzny$\mathrm{mi}$ - jako inwestycja $\mathrm{w}$ wojnę poczyniona $\mathrm{z}$ myślą o zyskach - a także $\mathrm{z}$ okresami niepobierania $\mathrm{w}$ ogóle tego podatku;

3. Płacenie z zachowaniem zasad dobrowolności, dążeniem państwa do gwarantowania nieuciążliwości świadczenia i nieegzekwowania pod przymusem;

4. Możliwość (według udokumentowanych źródeł minimum dwukrotną) zwracania poprzednio przez państwo pobranych i niewykorzystanych środków z tego tytułu;

5. Całkowite zwolnienia cives romani z płacenia tributu w wyniku przenoszenia bezpośrednich obciążeń finansowych państwa rzymskiego na nowo podbite obszary i narody;

Nie oznaczało to jednak zwolnienia obywateli z obowiązku ponoszenia innych świadczeń na rzecz państwa rzymskiego.

W średniowiecznej myśli podatkowej, zwłaszcza w tzw. wczesnych koncepcjach kameralistów nawiązujących do poglądów św. Tomasza z Akwinu, znajdują się także tezy o dopuszczalności stosowania podatków tylko w „przypadkach szczególnej konieczności”. Myśl podatkowa J. H.G. von Justi precyzyjnie naświetlała zagadnienia:

23 Ibidem, s. 31.

24 Z. Żywica, Wolność synów, [w:] Mateuszowe logia Jezusa. Studia z biblistyki, t. 7, red. ks. R. Bartnicki, Warszawa 1994, s. 47.

25 J. Klinkowski, Nowotestamentalny obraz celników na tle systemu finansowego Judei I Imperium Rzymskiego, „Perspektywa. Legnickie Studia Teologiczno-Historyczne” 2007, nr 2(11), s. 57.

26 A. Pikulska-Radomska, op. cit. s. 37-49.

27 P. Krajewski, op. cit., s.109. 
1. Uczciwej podstawy podatku;

2. Równomierności i sprawiedliwości opodatkowania ${ }^{28}$;

3. Relacji między bezpośrednim i pośrednim opodatkowaniem;

4. Zasad poboru podatków;

5. Granic zakresu opodatkowania, które są sformułowane następująco ${ }^{29}$ : „Podatki odciągają pieniądz z gospodarki, tak więc po ich opłaceniu nie może ona działać w tej samej skali co przedtem. Ważne jest, aby nie przekroczyć granic opodatkowania (...). Aby razem z pieniędzmi nie wyciskać z biednych poddanych krwi i potu”.

W konsekwencji oznaczało to, że zasady (zwłaszcza równomierność i sprawiedliwość) wymierzania podatku nie mogą być ustalone w sposób przekreślający gospodarcze oddziaływanie podatku. Zatem, dla dobra państwa potrzebującego harmonijnego rozwoju, należy tym samym unikać fiskalizmu.

Liberalna myśl podatkowa, $\mathrm{z}$ jej tezą o obiektywnych prawach natury funkcjonujących $\mathrm{w}$ gospodarce, $\mathrm{w}$ odniesieniu do zasad podatkowych, niezależnie od szczegółowych i wielorakich treści, kierowała się generalną regułą - należy chronić podatników przed działaniem władzy naruszającej „naturalny porządek $\mathrm{w}$ gospodarce" ${ }^{30}$. Sformułowała reguły dotyczące techniki pobierania podatków (pewność, dogodność, taniość). Oprócz przerzucalności (incydencji) podatkowej podniosła kwestie etyki opodatkowania pojmowanej jako dążenie do sprawiedliwego rozkładania ciężaru podatkowego ${ }^{31}$. Akcentowała konieczność ustanowienia gwarancji ochrony źródeł podatku. W konsekwencji krytycznie odnosiła się do fiskalizmu podatkowego, w którym upatrywała szczególne zło - niszczenia źródła podatku i destrukcyjny wpływ na dochody budżetu.

Analiza wybranych teorii podatkowych w odniesieniu do zakresu (granic stosowania) fiskalizmu prowadzi także do podniesienia niektórych dylematów i skrajnych rozbieżności w uzyskiwanych wynikach badań odnoszących się do makroekonomicznych konsekwencji stosowania fiskalizmu. W prawno-ekonomicznej literaturze $\mathrm{z}$ tego zakresu aktualnie często podejmowanym problemem jest związek pomiędzy rozmiarami sektora publicznego a stopą wzrostu gospodarczego. Nauki prawne (w szczególności prawno-finansowe) wykazują brak jednomyślności w swoich poglądach. Nauki ekonomiczne (neoklasyczna oraz endogeniczna teoria wzrostu gospodarczego) także traktują tę kwestię w sposób zupełnie odmienny. Według pierwszej z nich, skala redystrybucji nie wpływa

28 Szerzej w: L. Kurowski, Jak rozumieć sprawiedliwość, [w:] Podatki w orzecznictwie sądowym, red. E. Ruśkowski, W. Konieczny, Warszawa 1996.

29 Z. Fedorowicz, Historia podatków do końca XIX wieku - ze szczególnym uwzględnieniem Polski, [w:] Encyklopedia podatkowa, red. C. Kosikowski, Warszawa 1998, s. 58.

30 A. Gomułowicz, D. Mączyński, op. cit., s. 33.

31 Por. J. Głuchowski, Teorie podatkowe, [w:] System Prawa Finansowego, t. 3, red. L. Etel, Warszawa 2010, s. 89-97. 
na stopę wzrostu w długim okresie. $Z$ kolei druga przekonuje o negatywnym wpływie zarówno zbyt niskich, jak i wysokich wydatków państwa ${ }^{32}$. Wynikiem takiego stanu rzeczy jest fakt, że albo rząd dostarcza niedostateczną liczbę dóbr publicznych, albo zniekształcenia wywoływane przez podatki przewyższają korzyści płynące $\mathrm{z}$ ingerencji państwa. W światowej literaturze podejmowano także próby ${ }^{33}$ ustalenia zależności pomiędzy wysokością wydatków państwa, w szczególności ich strukturą a dobrobytem społecznym. Należy wskazać, że autorzy badań w swoich pracach częściej koncentrowali się jednak na konsumpcji rządowej niż na transferach.

Należy także zastanowić się nad odmiennymi podejściami i prezentowaną rozbieżnością oceny wyników badań empirycznych dotyczących roli fiskalizmu i jego wpływu na przebieg (zwłaszcza rozwój) procesów społeczno-gospodarczych. Z niektórych dotyczących badań wynika, że $\mathrm{e}^{34}$ :

1. Skala fiskalizmu nie wpływa na stopę wzrostu i rozwoju w długim okresie;

2. Istnieje negatywny wpływ zbyt niskich, jak i wysokich wydatków.

W światowej i polskiej literaturze można znaleźć różnorodne badania teoretyczno-empiryczne podejmujące próby ich weryfikacji. Obiektem badań były głównie kraje wysoko rozwinięte lub ich grupy (ugrupowania integracyjne) ze światowej gospodarki poza tylko nielicznymi przypadkami uwzględnienia w tym Polski. Niewątpliwie ważne są badania dotyczące Polski, w których zaprezentowano oddziaływanie na $\mathrm{PKB}$ poszczególnych podatków oraz obowiązkowych ubezpieczeń społecznych - jako składowych fiskalizmu ${ }^{35}$.

Wpływ fiskalizmu na długookresowe perspektywy wzrostu gospodarczego próbowano również ustalać analizując związek między długiem publicznym a wielkością wydatków publicznych oraz cyklicznością polityki fiskalnej. Tym samym kontynuując rozważania należy dokładniej przyjrzeć się problematyce długu publicznego, który także ma już swoją historię i przeszedł określoną ewolucję - przynajmniej od czasów św. Tomasza z Akwinu, który skupiał się na sprawiedliwej cenie długu. Wciąż jednak dług publiczny definiowany jest nie-

32 M. Bukowski, P. Kowal, P. Lewandowski, J. Zawistowski, Struktura i poziom wydatków i dochodów sektora finansów publicznych a sytuacja na rynku pracy. Doświadczenia międzynarodowe $i$ wnioski dla Polski, Warszawa 2005, s. 113.

33 Z. Hessami, The Size Composition of Government Spending in Europe and Its Impact on Well-Being, Wiley Blackwell, "Kyklos" 2010, t. 63 (3), s. 347.

34 M. Bukowski, P. Kowal, P. Lewandowski, J. Zawistowski, op. cit., s. 113 i n.

35 M. Grajewska, A. Maksimczuk, A. Świerczewska-Gąsiorowska, Fiskalizm a aktywność gospodarcza w Polsce. Aspekty ekonomiczno-prawne, granice stosowania, skutki, t. 1, Suwałki 2016; Eaedem, Fiskalizm a aktywność gospodarcza w Polsce. Aspekty ekonomiczno-prawne, granice stosowania, skutki, t. 2, Wpływ niektórych elementów składowych fiskalizmu na rozwój przedsiębiorczości i sektora MŚP w Polsce. Aspekt prawny z elementami porównań międzynarodowych, Suwałki 2016. 
jednolicie ${ }^{36}$. Według jego definicji leksykalnej dług publiczny to: „suma pieniędzy, którą ktoś pożyczył i musi zwrócić”, jak również „obowiązek dłużnika do spełnienia określonego świadczenia”. Określenie „publiczny” w konsekwencji oznacza także: „powszechny, pospolity, wszystkich albo wielu się tyczący, jawny"37. Według S. Owsiaka jest to: „finansowe zobowiązanie władz publicznych z tytułu zaciągnięcia kredytów i pożyczek, emisji papierów wartościowych oraz nieregulowania przez jednostki sektora publicznego wymagalnych zobowiązań” ${ }^{38}$. Eugeniusz Ruśkowski, odnosząc się do polskiego systemu sektora finansów publicznych, wskazuje na tożsamość pojęć państwowy dług publiczny oraz dług publiczny, które oznaczają dług sektora finansów publicznych ${ }^{39}$.

$\mathrm{W}$ związku $\mathrm{z}$ analizą wpływu długu publicznego na procykliczność polityki fiskalnej i konsolidacji finansowych na $\mathrm{PKB}^{40}$, podejmowano także próby zbadania czy dług publiczny, jako rezultat określonego zakresu fiskalizmu, ma wpływ na skalę wahań $\mathrm{PKB}^{41}$. Według J. Siwińskiej-Gorzelak, wielkość wydatków publicznych ma taki wpływ ${ }^{42}$. Również G.D. Myles potwierdził, że: „gdy we wszystkich krajach rozwiniętych dochody podatkowe w relacji do PKB wielokrotnie zwiększyły się, tempo wzrostu gospodarczego pozostawało na relatywnie stabilnym poziomie"43. Potwierdzało to dużo wcześniejszą (z końca ubiegłego stulecia) tezę, że: „zmiany opodatkowania wpływają na stopę wzrostu tylko przejściowo i stosunkowo krótko (...) w długim okresie są w stosunku do niej neutralne lub oddziałują jedynie na poziom produktu, a nie jego dynamikę (...) obniżenie wszystkich krańcowych i przeciętnych stawek podatkowych o odpowiednio: $5 \mathrm{pp}$. i $2,5 \mathrm{pp}$. w gospodarce USA prowadziło do przyspieszenia tempa jej wzrostu o $0,2-0,3$ pp. rocznie" 44 .

Niektóre badania z ostatniej dekady ubiegłego stulecia wskazały jednak istnienie negatywnej korelacji między stopą wydatków rządowych a wzrostem PKB, a inne to kwestionowały ${ }^{45}$. Istnienie związku potwierdził jednak

36 K. Nizioł, Próba zdefiniowania długu publicznego, „Roczniki Prawnicze” 2009, nr 20, s. 19; E. Ruśkowski, Finanse publiczne i prawo finansowe. Instrumenty prawnofinansowe $i$ warunki ich stosowania, Białystok 2018, s. 85-102.

37 E. Lotko, U.K. Zawadzka-Pąk, Prawnofinansowe instrumenty ograniczania deficytu i długu publicznego w Polsce na tle doświadczeń europejskich, Białystok 2018, s. 44-46.

38 S. Owsiak, Finanse publiczne. Teoria i praktyka, wyd. 3 zm., Warszawa 2013, s. 330.

39 E. Ruśkowski, op. cit., s. 85-102.

40 X. Debrun, R. Kapor, Fiscal policy and macroeconomic stability, "IMF Working Paper" 2010, $10 / 111$.

41 J. Siwińska-Gorzelak, Dlug publiczny a wzrost gospodarczy, Warszawa 2015.

42 J. Siwińska-Gorzelak, op. cit.

43 G.D. Myles, Economic Growth and the Role of Taxation, University of Exeter and Institute for Fiscal Studies, Prepared for the OECD, 2007.

44 E. Engen, J. Skinner, Taxation and Economic Growth, National Tax Association, "National Tax Journal" 1996, t. 49, nr 4.

45 J. Agell., H. Ohlsson, P. Thoursie, Growth Effects of Government Expenditure and Taxation in Rich Countries: A Comment, Elsevier, "European Economic Review" 2006, t. 50(1). 
C.I. Plosser badając kraje $\mathrm{OECD}^{46}$. Badanie 25 uprzemysłowionych krajów przyniosło jednak skrajnie zróżnicowane wyniki ${ }^{47}$. Gareth D. Mylesa, badając te zależności także w krajach OECD stwierdził, że: „wzrost stóp podatkowych o $10 \mathrm{pp}$. prowadzi do spadku stopy wzrostu gospodarczego o 0,5 pp. - dodając do tego, że spadek ten jest nieznacznie wyższy w przypadku oddziaływania podatków bezpośrednich niż pośrednich"48.

Bezpośredni wpływ poziomu fiskalizmu na stopę wzrostu PKB potwierdzili nieco później G. Karras i D. Furceri - ustalając, że: „wzrost stopy obciążeń fiskalnych o $1 \%$ PKB prowadzi w długim horyzoncie czasowym do trwałego spadku PKB per capita (spadek o 0,5-1\%, w zależności od specyfikacji zastosowanego modelu) ${ }^{\prime 49}$. Na potwierdzenie tak sformułowanej tezy nie pozwalał jednak dokonany skrupulatny przegląd literatury przedmiotu i wyników innych badań empirycznych stosujących krańcowe stawki podatkowe do wyjaśnienia związku między polityką fiskalną a wzrostem PKB i podsumowanych stwierdzeniem: „(...) dowody na to, że stopy podatkowe oddziałują na wzrost są niepokojąco kruche" 50 .

\section{Szczególne znaczenie zakresu fiskalizmu w sytuacjach kryzysowych - w tym w okresie epidemii COVID-19}

W polskiej literaturze widoczny jest niedostatek oryginalnych badań empirycznych podejmujących wpływ fiskalizmu na wzrost i rozwój zwłaszcza w zależności od faz cyklu koniunkturalnego. Jako nieliczni (A. Siwy, A. Adamczyk i inni) próbowali weryfikować zależności między wysokością i strukturą dochodów fiskalnych a tempem wzrostu gospodarczego w krajach Unii Europejskiej (14 krajów z UE-15, z wyłączeniem Luksemburga) w latach 1991-2000. Do pomiaru kierunku i siły zależności między poziomem fiskalizmu a średnim rocznym tempem wzrostu gospodarczego używali współczynnika korelacji liniowej Pearsona. Otrzymana wartość współczynnika $(-0,56)$ świadczyła o istnieniu statystycznie istotnej ujemnej zależności między średnim poziomem fiskalizmu a tempem wzrostu gospodarczego. Pokazały, że: „wzrost poziomu fiskalizmu o 1 pp. powoduje spadek tempa wzrostu gospodarczego na jednego mieszkańca o 0,14 pp.”51. Dawało to przesłankę do postawienia tezy, że: „negatywny

46 C.I. Plosser, The Search for Growth, [w]: Policies for Long-Run Economic Growth, red. J. Hole, Wyoming 1992, s. 27-29.

47 F. Padovano, E. Galli, Comparing the Growth Effects of Marginal vs. Average Tax Rates and Progressivity, "European Journal of Political Economy" 2002, t. 18.

48 G.D. Myles, op. cit.

49 G. Karras, D. Furceri, Taxes and Growth in Europe, "South-Eastern Europe of Economics" 2009, nr 2.

50 G.D. Myles, op. cit.

51 A. Siwy, A. Adamczyk, T. Lubińska, W. Tarczyński, Poziom fiskalizmu a bezrobocie i tempo zmian PKB w krajach Unii Europejskiej i w Polsce w latach 1990-2000, „Ekonomista” 2004, nr 1. 
wpływ obciążeń fiskalnych na dynamikę wzrostu gospodarczego jest zauważalny dopiero w długim okresie". Podobne wnioski uzyskali również B. Wrona i T. Wołowiec, którzy przeprowadzili badania tej samej grupy krajów z rozszerzeniem jednak danych wejściowych modelu o kolejne cztery lata (1991-2004) ${ }^{52}$.

Analizując wpływ fiskalizmu na wzrost i rozwój należy odnieść się do stosunkowo nowych (2016 r.) badań nad wpływem fiskalizmu na aktywność gospodarczą w Polsce ${ }^{53}$. Odtwórczo wykorzystane wyniki światowych badań tych zależności stały się punktem wyjścia do analizy wpływu najważniejszych składowych (CIT, VAT, PIT i obowiązkowe ubezpieczenia społeczne) fiskalizmu na aktywność podmiotów gospodarujących (mikroskala) i PKB (makroskala) $\mathrm{w}$ Polsce. Sformułowano rekomendacje dla - w przyszłości realizowanej polskiej polityki fiskalnej. Z pewnością można w nich znaleźć także te, które aktualnie mogą przydać się w poszukiwaniu rozwiązań skutecznych w pokonywaniu specyficznego załamania gospodarczego zaistniałego $\mathrm{w}$ wyniku epidemii COVID-19.

Ze względu na płynną granicę i silne zróżnicowanie poszczególnych gospodarek narodowych jednoznacznie (nawet w ramach tego samego ugrupowania integracyjnego) w aspekcie ekonomicznym i prawnym trudno jest określić, czy dane państwo charakteryzuje się nadmiernym fiskalizmem. Znacznie łatwiej jest porównać poziom fiskalizmu $\mathrm{w}$ danym kraju $\mathrm{z}$ jego skalą $\mathrm{w}$ innych państwach, chociaż różny jest zakres finansów publicznych w systemach zarządzania poszczególnych krajów. Do jego pomiaru należy do PKB odnosić zarówno dochody, jak i wydatki publiczne. Stąd też mają tutaj zastosowanie:

1. Wskaźnik socjalizacji (wydatki);

2. Wskaźnik fiskalizmu (dochody).

Zdaniem E. Ruśkowskiego ${ }^{54}$ lepszym jest pierwszy $\mathrm{z}$ nich, chociaż $\mathrm{w}$ badaniach naukowych wymagających pogłębionego ujęcia należy stosować także drugi z nich - m.in. w związku z niepełną ściągalnością podatków i tym samym różnym zakresem luki podatkowej w poszczególnych krajach ${ }^{55}$. Do tych wskaźników dodatkowo wykorzystuje się takie mierniki, jak: wysokość stawek podatkowych, poziom obciążeń fiskalnych w stosunku do PKB, zakres ingerencji systemu finansów publicznych w PKB, stopień pokrycia wydatków publicznych dochodami publicznymi, budowa i skala stosowanych przedziałów podatkowych, różnice między nominalną a efektywną stopą opodatkowania oraz zakres występowania szarej strefy w gospodarce ${ }^{56}$.

52 B. Wrona, T. Wołowiec, Struktura systemu podatkowego a wzrost gospodarczy, „Zeszyty Naukowe” 2007, nr 6.

53 M. Grajewska, A. Maksimczuk, A. Świerczewska-Gąsiorowska, op. cit., t. 1 i 2.

54 E. Ruśkowski, op. cit., s. 31.

55 Ibidem, s. 183.

56 M. Dynus, Fiskalizm w Unii Europejskiej, „Bank i Kredyt” 2007, nr 2. 
Współcześnie w tego typu badaniach zastosowanie mają trzy główne mierniki fiskalizmu. Są to ${ }^{57}$ :

1. Stopa podatkowa (tax ratio), będąca relacją wpływów podatkowych do PKB;

2. Stopa obciążeń fiskalnych ogółem (total tax revenue as percentage GDP) jako relacja sumy obciążeń finansowych, obejmujących nie tylko podatki, lecz także niepodatkowe dochody budżetu państwa oraz wszelkie obligatoryjne zobowiązania (jak składki na ubezpieczenia społeczne oraz alimentację funduszy celowych) do produktu krajowego brutto (PKB);

3. Stopa wydatków państwa (government spending ratio lub government total outlays as percentage of GDP), przedstawiająca relację całkowitych wydatków państwa, budżetów gmin, wypłat na ubezpieczenia społeczne oraz wydatków pozostałych państwowych funduszy celowych, a także agencji i fundacji, do produktu krajowego brutto (PKB).

W Unii Europejskiej stopa obciążen fiskalnych ogótem jest od dłuższego czasu najczęściej stosowaną miarą fiskalizmu. Nie wyklucza to praktycznego stosowania także innych tego miar (w miarę potrzeby uzupełnianych tzw. informacjami dodatkowymi). Wynika to zwłaszcza z następujących powodów ${ }^{58}$ :

- praktyka zarządzania budżetem i długiem publicznym powoduje, że z tych względów skala fiskalizmu występuje w postaci oceny udziału łącznej sumy podatków i parapodatków w PKB;

- przy ocenie nadmiernego fiskalizmu coraz częściej jest podnoszony argument, że wysokie podatki i quasi podatkowe daniny publiczne sprzyjają rozwojowi szarej strefy;

- $\quad$ analizy porównawcze dochodów podatkowych i systemów podatkowych różnych krajów prowadzone bez odniesienia do kwestii i zakresu obciążeń fiskalnych z tytułu szeroko rozumianego zabezpieczenia społecznego mogą prowadzić do sformułowania wadliwych wniosków.

Zwłaszcza w fazie recesji i w warunkach wychodzenia ze stanu załamania gospodarczego zazwyczaj, oprócz tendencji do wzrostu zakresu stosowania fiskalizmu, dostrzega się także wyraźne jego zróżnicowanie między poszczególnymi krajami. Przykładowo, w UE w warunkach kryzysu 2008 r., przedstawiało się ono następująco ${ }^{59}$ :

57 M. Grajewska, A. Maksimczuk, A. Świerczewska-Gąsiorowska, op. cit., t. 1, s. 79-80.

58 A. Siwy, A. Adamczyk, T. Lubińska, W. Tarczyński, op. cit.

59 Taxation Trends in the European Union. Data for the EU Member States, Iceland and Norway, European Commission - Eurostat, Luxembourg 2011. 
Tabela 1. Poziom fiskalizmu w 2010 r. w wybranych krajach UE

\begin{tabular}{lllll}
\hline Lp. & Miernik fiskalizmu & Przeciętna UE & Kraj i poziom max. & Kraj i poziom min. \\
\hline 1 & Stopa podatkowa & $24,6 \%$ & Dania $46,6 \%$ & Czechy $18,5 \%$ \\
\hline 2 & Stopa obciążeń fiskalnych & $35,6 \%$ & Dania $47,6 \%$ & Litwa $27,1 \%$ \\
\hline 3 & Stopa wydatków państwa & $50,3 \%$ & Irlandia $67,0 \%$ & Bułgaria $37,7 \%$ \\
\hline
\end{tabular}

Źródło: Public Finances in EMU-2011, European Economy, European Commission, DirectorateGeneral for Economic and Financial Affairs, Brussels 2010, 3/2011, s. 28; Taxation Trends in the European Union. Data for the EU Member States, Iceland and Norway, European Commission - Eurostat, Luxembourg 2011, s. 180.

Z analizy powyższych danych wynika wyraźnie, że trudno jest wskazać jednoznacznie kraj, w którym poziom fiskalizmu byłby skrajnie najwyższy lub najniższy. W zależności od miernika, przyjmowanego do oceny skrajnych (min. lub max.) wielkości wchodzą (oprócz Danii na podstawie dwóch początkowych mierników) coraz to inne kraje. Oprócz wniosku potwierdzającego wpływ wybranego miernika na ocenę skali fiskalizmu w tego typu badaniach należy wskazać także uzasadnienie podejmowania jeszcze bardziej uszczegółowionych badań tych zależności. Jest to istotnie ważne w poszukiwaniu indywidualnych dla każdego kraju skutecznych sposobów oddziaływania także na przebieg cykli koniunkturalnych - w szczególności wychodzenia ze stanów kryzysów i recesji, jest to wyjątkowo ważne także w Polsce w warunkach epidemii COVID-19.

$\mathrm{W}$ czasach recesji (obecnie znajdujemy się $\mathrm{w}$ takim okresie $\mathrm{w}$ związku z COVID-19) rośnie także waga badań podnoszących kwestie cykliczności procesów gospodarczych. Podejmowane są próby wyjaśnienia źródła nowo zaistniałego kryzysu. Poszukiwane są odpowiedzi na pytanie, czy można było temu zapobiec i jak w przyszłości można łagodzić skutki kryzysów. Tym samym analiza długookresowych zmian w przebiegu cyklu Kondratiewa może mieć szczególne znaczenie w wyjaśnianiu przyczyn poprzedniej (2008 r.) recesji z początków XXI w. Może też okazać się szczególnie przydatną do poszukiwania sposobów łagodzenia skutków i wychodzenia $\mathrm{z}$ obecnie istniejącego załamania gospodarczego. Tym samym uzasadniona staje się analiza wyników znaczących światowych badań dotyczących modyfikacji (deformacji) przebiegu cyklu Kondratiewa w II połowie XX i na początu XXI w.

Analizę należy zacząć od Oscara Jorda, który wraz ze współautorami ${ }^{60}$, na podstawie kompleksowej analizy PKB w 17 krajach wykazali, że cykle po II wojnie światowej uległy licznym odchyleniom. Nastąpiło w nich m.in. skrócenie i zmniejszenie amplitudy fazy spadkowej, wydłużenie czasu trwania

60 O. Jorda, M. Schularick, M.A.J.P. Taylor, Macrofinancial history and the new business cycle facts, "National Bureau of Economic Research" 2016, t. 22743. 
fazy ekspansji ze zmianą długości cyklu ${ }^{61}$. Autorzy zwrócili także uwagę na synchronizację cykli, akcelerację tempa rozchodzenia się poszczególnych faz na kolejne kraje oraz na zwiększenie zasięgu. Badania Korotayeva oraz Tsirela z 2010 r. $^{62}$, podzielają także pogląd o dyskusyjnym charakterze cyklu Kondratiewa, twierdząc, że tzw. faza wzrostowa V cyklu trwała od 1985 do 2008 r. Natomiast spadkowa może trwać (przez prawie 25 lat) do około 2035 r. Oznaczałoby to wyraźną dysproporcję w porównaniu do poprzednich cykli. Przypuszczają, że cykl V także uległ skróceniu i może trwać do 2020-2025 r. Ze względu na sieć powiązań i zależności ekonomicznych państw, efekt domina oraz „zarażania się” kryzysem kolejnych sektorów gospodarki na całym świecie może być dużo silniejszy niż w poprzednich cyklach i dotknąć zdecydowaną większość państw na świecie.

Leo i Simone Nefiodow w 2014 r. ${ }^{63}$ zaprezentowali model, w którym wyróżniono już kolejny, szósty cykl Kondratiewa. Trwał on od 1990 r. i był wywołany rozwojem bioinżynierii i medycyny. Zwracają też uwagę na podejmowanie przez rządy interwencji w okresach spowolnienia gospodarczego czy kryzysu, co może znacząco wpływać na długość i przebieg cyklu. Ze względu na ingerencje władz w gospodarkę, okresy recesji mogą także być nieznacznie dłuższe. Jednakże skutki załamań gospodarczych mogą być zdecydowanie mniej odczuwalne. Podobną teorię (o skróceniu cyklu Kondratiewa) zaprezentowali także Leonid i Anton Grinin $^{64}$. Twierdzą, że kolejny cykl będzie krótszy od poprzedniego ze względu na tempo postępu. Jednak po kolejnej wielkiej rewolucji przemysłowej (przewidywanej na początek XXII w), cykle znowu wydłużą się i w nowym wieku będą również ulegać skróceniu. Podobnie jak L. i S. Nefiodow wskazują na bioinżynieryjne podstawy cyklu VI - dodając też postęp w zakresie cybernetyki i kognitywistyki. Inaczej jednak charakteryzują ramy czasowe cyklu. Uważają, że IV cykl Kondratiewa trwał do 1980-1985 r, zaś V - do 2020 r. Z kolei już VI cykl może zakończyć się dopiero w okolicach 2050 r., a w najbliższym czasie czekają nas czasy ożywienia ${ }^{65}$.

Wyniki wyżej zaprezentowanych wybranych światowych badań pokazują, że wciąż jeszcze nie jest możliwe jednoznaczne stwierdzenie, w którym cyklu

61 M. Maksimczuk, Fiskalizm a wzrost gospodarczy. Analiza wybranych wyników badań ze światowej i polskiej literatury, [w:] Znaczenie ekonomii we współczesnym świecie, Kraków 2020, s. 143-153.

62 A. Korotayev, S. Tsirel, A spectral analysis of world GDP dynamics: Kondratieff Waves, Kuznets Swings, Juglar and Kitchin Cycles in global economic development and the 2008-2009 economic crisis, "Structure and Dynamics" 2010, t. 4(1).

63 L. Nefiodow, S. Nefiodow, The sixth Kondratieff. The new long wave in global economy, Sankt Augustin 2014.

64 L. Grinin, A. Grinin, The sixth Kondratieff wave and the cybernetic revolution, [w:] Globalistics and globalization studies: Global Transformations and Global Future, Uchitel Publishing House 2016, s. 337-355.

65 M. Maksimczuk, op. cit., s. 143-153. 
obecnie znajduje się światowa gospodarka. Wyznaczenie pewnych ram czasowych dla większości powojennych cyklów nie jest na ten moment możliwe. Również analiza przebiegu fal, zdaniem badaczy, powinna być powtórzona po roku 2040. W odniesieniu jednak do obecnej sytuacji warto podkreślić, że wskazują one rok 2020 jako należący do fazy spadkowej, w której możliwa jest głęboka recesja gospodarcza. Niewątpliwie te przypuszczenia potwierdziły się wraz z epidemią COVID-19. Potencjalna deformacja cyklu w zakresie długości trwania, czy też spłycenie okresu recesji, wynika ze wzrostu tempa postępu technologicznego oraz szerszego wykorzystywania narzędzi polityki pieniężnej i fiskalnej. Wprawdzie wykorzystanie tych narzędzi może prowadzić do łagodzenia skutków kryzysów gospodarczych, ale w pewnych uwarunkowaniach (m.in. epidemii wywołanej przez COVID-19) może też okazywać się niewystarczające do uchronienia świata przed kolejnym wielkim kryzysem. Zdecydowanie większy zakres fiskalizmu, obniżanie stóp procentowych, czy też oferowanie szerokiej gamy pakietów socjalnych, zdaniem wielu analityków, może trwać tylko do określonych poziomów. Faktycznie zaistniała już nadmierna kumulacja tych niekorzystnych zjawisk może spowodować, że w pewnym momencie nie zaistnieją już działania mogące powstrzymać $\mathrm{kryzys}^{66}$.

\section{Podsumowanie i wnioski}

Praktyka życia społeczno-gospodarczego zawsze stawiała określone zadania naukom prawnym i ekonomicznym. Badania naukowe, w poszukiwaniu nowych rozwiązań, nie mogą pomijać już istniejącego dorobku z danego zakresu. Wnikliwa analiza funkcjonujących teorii, w powiązaniu z oceną efektów w praktyce gospodarczej, pozwala lepiej wywiązywać się z realizacji tych zadań. Zagadnienia omówione w niniejszym opracowaniu odnoszą się do problematyki fiskalizmu i nie są kwestiami zupełnie nowymi w teorii i praktyce gospodarczej. Współczesne życie społeczno-gospodarcze pokazuje jednak, że są one wciąż ważne i aktualne. W niektórych sytuacjach, zwłaszcza w okresach występowania przejawów sytuacji kryzysowych, nabierają rosnącego teoretycznego i praktycznego znaczenia.

Analizując literaturę przedmiotu można stwierdzić, że podejmowano wiele prób zidentyfikowania związku fiskalizmu i długu publicznego z PKB. Nie zawsze jednak uzyskiwano z tych badań konkretnie brzmiące rezultaty. Do przezwyciężenia były też różnorodne problemy o charakterze metodologicznym. Badania zmierzały zazwyczaj w kierunku poszukiwania długookresowych determinant wzrostu gospodarczego na podstawie danych panelowych lub

66 E. Pancer-Cybulska, Działania UE wobec krajów dotkniętych kryzysem fiskalnym, „Studia Ekonomiczne. Zeszyty Naukowe Uniwersytetu Ekonomicznego w Katowicach” 2018, nr 347, s. 9-21. 
przekrojowych. Wprowadzenie do badań odpowiednich instrumentów i zmiennych kontrolnych jest jednak szczególnie istotne dla możliwości wiarygodnej interpretacji osiąganych wyników i w konsekwencji tego także ich przydatności do podejmowania trafnych decyzji polityki gospodarczej. Wyzwaniem $\mathrm{w}$ stosunku do modeli regresji jest także potencjalna endogeniczność niektórych zmiennych niezależnych. Ich zmiany $\mathrm{w}$ rzeczywistości mogą odzwierciedlać wahania wzrostu gospodarczego, nie będąc tego faktycznym determinantem. Niekwestionowanym faktem jest, że zjawiska kryzysowe aktywizują konieczność sięgania po różnorodne instrumenty fiskalizmu. Nowe badania, wsparte doświadczeniami i wnioskami powinny stawać się bardziej przydatnymi i lepiej wspomagać podejmowanie trafnych decyzji nawet $\mathrm{w}$ znacznie bardziej skomplikowanych uwarunkowaniach funkcjonowania współczesnej gospodarki - w tym w czasie epidemii COVID-19.

W obecnych warunkach funkcjonowania gospodarki światowej, ugrupowań integracyjnych i poszczególnych krajów zachodzi szczególnie uzasadniona potrzeba prowadzenia takich rozważań. Wprawdzie sytuacje kryzysowe znane są od dawna, ale każdy następny kryzys jest pod wieloma względami inny od poprzednich. Nowe, a tym bardziej współcześnie zaistniałe, uwarunkowania funkcjonowania gospodarki i społeczeństwa, wymagają weryfikacji wielu poprzednio już podejmowanych skutecznych (ale też i tych, które zawiodły lub okazywały się tylko nieznacznie skuteczne) rozwiązań. Czynione w niniejszej publikacji rozważania pozwoliły na pozytywne zweryfikowanie postawionej hipotezy badawczej oraz na sformułowanie następujących wniosków:

1. Rośnie rola, znaczenie i zakres stosowanego fiskalizmu - zwłaszcza w związku z dążeniem do jak najszybszego wyjścia z kryzysu. W konsekwencji prowadzi to do zmian poziomu innych makroekonomicznych wielkości i relacji;

2. Nasilanie się zjawisk kryzysowych jeszcze bardziej aktywizuje konieczność sięgania po różnorodne instrumenty fiskalizmu - poprzednio mało (nawet nie stosowane) wykorzystywane;

3. Niewątpliwie zakres stosowanego fiskalizmu wywiera określone bieżące i przyszłe (średnio- i nawet długookresowe) skutki społeczno-gospodarcze. Jest to ważnym i wyjątkowo trudnym dylematem wyboru w polityce $\mathrm{z}$ tego zakresu, ponieważ także $\mathrm{w}$ tym obszarze nie zawsze jest możliwa do zastosowania racjonalność w skonfrontowaniu teraźniejszości z przyszłością;

4. Światowe i polskie przykłady już zrealizowanych badań niewątpliwie wniosły odpowiedni wkład w zbadanie tutaj prezentowanych zależności;

5. Istnieje potrzeba realizacji nowych tego typu badań odnoszących się także do sytuacji poszczególnych krajów - w tym do polskiej gospodarki w okresie epidemii COVID-19. 


\section{Bibliografia}

Agell J., Ohlsson H., Thoursie P., Growth Effects of Government Expenditure and Taxation in Rich Countries: A Comment, Elsevier, "European Economic Review" 2006, t. 50 (1).

Bartnicki R. (red.), Mateuszowe logia Jezusa. Studia z biblistyki, t. 7, Warszawa 1994.

Bukowski M., Kowal P., Lewandowski P., Zawistowski J., Struktura i poziom wydatków i dochodów sektora finansów publicznych a sytuacja na rynku pracy. Doświadczenia międzynarodowe i wnioski dla Polski, Warszawa 2005.

Debrun X., Kapor R., Fiscal policy and macroeconomic stability, "IMF Working Paper" 2010, 10/111.

Dynus M., Fiskalizm w Unii Europejskiej, „Bank i Kredyt” 2007, nr 2.

Encyklopedia podatkowa, red. C. Kosikowski, Warszawa 1998.

Engen E., Skinner J., Taxation and Economic Growth, "National Tax Association, National Tax Journal" 1996, t. 49, nr 4.

Etel L. (red.), System Prawa Finansowego, t. 3, Warszawa 2010.

Fedorowicz Z., Historia podatków do końca XIX wieku - ze szczególnym uwzględnieniem Polski, [w:] Encyklopedia podatkowa, red. C. Kosikowski, Warszawa 1998.

Gajl N., Teorie podatkowe w świecie, Warszawa 1992.

Głuchowski J., Teorie podatkowe, [w:] System Prawa Finansowego, red. L. Etel, t. 3, Warszawa 2010.

Gomułowicz A., Mączyński D., Podatki i prawo podatkowe, Seria Akademicka, wyd. 8, Warszawa 2016.

Grajewska M., Maksimczuk A., Świerczewska-Gąsiorowska A., Fiskalizm a aktywność gospodarcza w Polsce. Aspekty ekonomiczno-prawne, granice stosowania, skutki, t. 1, Suwałki 2016.

Grajewska M., Maksimczuk A., Świerczewska-Gąsiorowska A., Fiskalizm a aktywność gospodarcza w Polsce. Aspekty ekonomiczno-prawne, granice stosowania, skut$k i$, t. 2, Wpływ niektórych elementów składowych fiskalizmu na rozwój przedsiębiorczości i sektora MŚP W Polsce. Aspekt prawny z elementami porównań międzynarodowych, Suwałki 2016.

Grinin L., Grinin A., The sixth Kondratieff wave and the cybernetic revolution, [w:] Globalistics and globalization studies: Global Transformations and Global Future, Volgograd 2016.

Hessami Z., The Size Composition of Government Spending in Europe and Its Impact on Well-Being, Wiley Blackwell, "Kyklos" 2010, t. 63 (3).

Jorda O., Schularick M., Taylor A.M., Macrofinancial history and the new business cycle facts, "National Bureau of Economic Research", t. 22743.

Karras G., Furceri D., Taxes and Growth in Europe, "South-Eastern Europe of Economics" 2009, nr 2.

Klinkowski J., Nowotestamentalny obraz celników na tle systemu finansowego Judei i Imperium Rzymskiego, „Perspektywa. Legnickie Studia Teologiczno-Historyczne” 2007, nr 2 (11). 
Korotayev A., Tsirel S., A spectral analysis of world GDP dynamics: Kondratieff Waves, Kuznets Swings, Juglar and Kitchin Cycles in global economic development and the 2008-2009 economic crisis, "Structure and Dynamics" 2010, t. 4 (1).

Krajewski P., Finanse publiczne, [w:] Rzymskie prawo publiczne, red. B. Sitek, P. Krajewski, Olsztyn 2004.

Kurowski L., Jak rozumieć sprawiedliwość, [w:] Podatki w orzecznictwie sądowym, red. E. Ruśkowski, W. Konieczny, Warszawa 1996.

Lotko E., Zawadzka-Pąk U.K., Prawnofinansowe instrumenty ograniczania deficytu i dtugu publicznego w Polsce na tle doświadczeń europejskich, Białystok 2018.

Maksimczuk M., Fiskalizm a wzrost gospodarczy. Analiza wybranych wyników badań ze światowej i polskiej literatury, [w:] Znaczenie ekonomii we współczesnym świecie, Kraków 2020.

Myles G.D., Economic Growth and the Role of Taxation, University of Exeter and Institute for Fiscal Studies, Prepared for the OECD, 2007.

Nefiodow L., Nefiodow S., The sixth Kondratieff. The new long wave in global economy, Sankt Augustin: CreateSpace Independent Publishing Platform, 2014.

Nizioł K., Próba zdefiniowania długu publicznego, „Roczniki Prawnicze” 2009, nr 20.

Owsiak S., Finanse publiczne. Teoria i praktyka, wyd. 3 zm., Warszawa 2013.

Padovano F., Galli E., Comparing the Growth Effects of Marginal vs. Average Tax Rates and Progressivity, "European Journal of Political Economy" 2002, t. 18.

Pancer-Cybulska E., Działania UE wobec krajów dotkniętych kryzysem fiskalnym, „Studia Ekonomiczne. Zeszyty Naukowe Uniwersytetu Ekonomicznego w Katowicach" 2018, nr 347.

Pikulska-Radomska A., Uwagi o rzymskim fiskalizmie epoki wczesnego cesarstwa, „Studia Iuridica Toruniensia" 2012, t. 10.

Plosser C.I., The Search for Growth, w: Policies for Long-Run Economic Growth, Wyoming 1992, August 27-29.

Podatki w orzecznictwie sądowym, red. E. Ruśkowski, W. Konieczny, Warszawa 1996.

Ricardo D., Zasady ekonomii politycznej i opodatkowania, Warszawa 1957.

Ruśkowski E., Finanse publiczne i prawo finansowe. Instrumenty prawnofinansowe i warunki ich stosowania, Białystok 2018.

Rzymskie prawo publiczne, red. B. Sitek, P. Krajewski, Olsztyn 2004.

Say J.B., Traktat o ekonomii politycznej, czyli prosty wykład sposobu, w jaki się tworza, rozdzielaja i spożywaja bogactwa, Warszawa 1960.

Sismonde de Sismondi J.C.I., Nowe zasady ekonomii politycznej, czyli o bogactwie i jego stosunku do ludności, t. 2, Warszawa 1955.

Siwińska-Gorzelak J., Dług publiczny a wzrost gospodarczy, Warszawa 2015.

Siwy A., Adamczyk A., Lubińska T., Tarczyński W., Poziom fiskalizmu a bezrobocie i tempo zmian PKB w krajach Unii Europejskiej iw Polsce $w$ latach 1990-2000, „Ekonomista” 2004, nr 1.

Smith A., Badania nad natura i przyczynami bogactwa narodów, Warszawa 2003. 
Szczodrowski G., Polski system podatkowy. Strategia transformacji, Gdańsk 2002.

Taxation Trends in the European Union. Data for the EU Member States, Iceland and Norway, European Commission - Eurostat, Luxembourg 2011.

Wrona B., Wołowiec T., Struktura systemu podatkowego a wzrost gospodarczy, „Zeszyty Naukowe Wyższej Szkoły Ekonomicznej w Bochni” 2007, nr 6.

Żywica Z., Wolność synów, [w:] Mateuszowe logia Jezusa. Studia z biblistyki, t. 7, red. R. Bartnicki, Warszawa 1994.

\section{STRESZCZENIE}

Uzasadnione jest prezentowanie zagadnień odnoszących się do ewolucji teorii i praktyki stosowania fiskalizmu na świecie i w Polsce. Nie należą one do relatywnie najnowszych, pozostają jednak wciąż ważnymi i aktualnymi we współczesnej gospodarce, szczególnie w obecnych warunkach nasilania się zjawisk kryzysowych - w tym ostatnich spowodowanych epidemią COVID-19. W związku z tym celem jest próba przedstawienia ewolucji poglądów z teorii i praktyki gospodarczej w kwestii podatków i fiskalizmu z możliwością pogłębiania rozważań nad takimi elementami, aspektami i kierunkami zmian, które odpowiednio zmodyfikowane do nowych warunków mogą być przydatne także współcześnie w poszukiwaniu dróg wychodzenia z kryzysów w tym zwłaszcza z obecnego związanego z epidemią COVID-19. Postawiono hipotezę badawczą, że: problematyka fiskalizmu i długu publicznego jest wciąż ważna i we współczesnej gospodarce nabiera szczególnego znaczenia - zwłaszcza w warunkach poszukiwania dróg wychodzenia z kryzysów. W pierwszej części zaprezentowano zarys rozwoju podejścia do podatków i fiskalizmu w myśli prawno-ekonomicznej od starożytności po współczesność. Druga część podnosi kwestie zakresu (granic) stosowania podatków i fiskalizmu. Rozważania teoretyczne wsparto odtwórczo wybranymi ze światowej literatury wynikami badań empirycznych dotyczących zależności między stosowanym zakresem fiskalizmu a osiąganymi wskaźnikami wzrostu i rozwoju. Trzecia odnosi się do szczególnego znaczenia fiskalizmu w sytuacjach kryzysu. Konkluzje i wnioski z zaprezentowanych w poprzedniej części badań empirycznych dotyczących zwłaszcza kryzysu z 2008 r., na tle wyników badań przebiegu i współczesnej modyfikacji długich cykli koniunkturalnych, odniesiono do obecnego kryzysu wywołanego epidemią COVID-19. Z czynionych rozważań wyprowadzone zostały uogólnienia i wnioski pozwalające pozytywnie zweryfikować wcześniej postawioną hipotezę badawczą. 


\section{SUMMARY}

\section{The Theory and Practice Development of Applying Fiscalism in the World and Poland Regarding the COVID-19 Modern Epidemic Situation}

It is reasonable to raise issues relating to the evolution of the theory and practice of fiscalism in the world and Poland. They are not relatively recent. However, they remain important and valid in the contemporary economy, especially in the current intensifying crisis occurrences - including the recent ones caused by the COVID-19 pandemic. Therefore, the subject has aimed at presenting a study providing an overview including taxation and fiscalism with the potential for further consideration of aspects and directions of change which, suitably modified for the new conditions, may also be helpful nowadays in seeking ways out of economic crises, especially the most recent one related to the COVID-19 pandemic. The research hypothesis has been put forward that fiscalism and public debt are still essential and in today's economy acquire particular relevance - especially in the conditions of seeking ways out of crises. The first part presents an outline of the development of the approach to taxes and fiscalism in legal and economic thought from ancient times to the present. The second part raises the range (limits) of the application of taxes and fiscalism. The theoretical considerations are supported by empirical research results reproductively selected from the world literature on the relationship between the applied scope of fiscalism and the achieved growth and development indicators. The third refers to the unique significance of fiscalism in crises. The conclusions and inferences from the empirical research presented in the previous part, concerning, in particular, the 2008 crisis against the background of the results of the research on the course and new modification of long economic cycles, were referred to the current crisis caused by the COVID-19 pandemic. Generalizations and conclusions allowing for positive verification of the earlier research hypothesis were derived from the considerations. 